\title{
Induced lung inflammation and dietary protein supply affect nitrogen retention and amino acid metabolism in growing pigs
}

\author{
Esther Kampman-van de Hoek ${ }^{1,2}$, Panagiotis Sakkas², Walter J. J. Gerrits ${ }^{2}$, Joost J. G. C. van den Borne ${ }^{2}$, \\ Carola M. C. van der Peet-Schwering ${ }^{1}$ and Alfons J. M. Jansman ${ }^{1 *}$ \\ ${ }^{1}$ Department of Animal Nutrition, PO Box 338, 6700 AH Wageningen, The Netherlands \\ ${ }^{2}$ Animal Nutrition Group, Wageningen University, PO Box 338, 6700 AH Wageningen, The Netherlands
}

(Submitted 1 May 2014 - Final revision received 13 October 2014 - Accepted 22 October 2014 - First published online 21 January 2015)

\begin{abstract}
It is hypothesised that during immune system activation, there is a competition for amino acids (AA) between body protein deposition and immune system functioning. The aim of the present study was to quantify the effect of immune system activation on $\mathrm{N}$ retention and AA metabolism in growing pigs, depending on dietary protein supply. A total of sixteen barrows received an adequate (Ad) or restricted (Res) amount of dietary protein, and were challenged at day 0 with intravenous complete Freund's adjuvant (CFA). At days $-5,3$ and 8 , an irreversible loss rate (ILR) of eight AA was determined. CFA successfully activated the immune system, as indicated by a 2- to 4-fold increase in serum concentrations of acute-phase proteins (APP). Pre-challenge C-reactive protein concentrations were lower $(P<0 \cdot 05)$ and pre- and post-challenge albumin tended to be lower in Res-pigs. These findings indicate that a restricted protein supply can limit the acute-phase response. CFA increased urinary $\mathrm{N}$ losses $(P=0.04)$ and tended to reduce $\mathrm{N}$ retention in Ad-pigs, but not in Res-pigs $(P=0.07)$. The ILR for Val was lower $(P=0.05)$ at day 8 than at day 3 in the post-challenge period. The ILR of most AA, except for Trp, were strongly affected by dietary protein supply and positively correlated with $\mathrm{N}$ retention. The correlations between the ILR and APP indices were absent or negative, indicating that changes in AA utilisation for APP synthesis were either not substantial or more likely outweighed by a decrease in muscle protein synthesis during immune system activation in growing pigs.
\end{abstract}

Key words: Inflammation: Amino acid metabolism: Dietary amino acid supply: Growing pigs

During immune system activation in animals, nutrients are redistributed from anabolic and maintenance processes towards processes involved in immunity and disease resistance $^{(1,2)}$. A cascade of cytokine-induced metabolic alterations occur, including anorexia, increased breakdown and decreased synthesis of skeletal muscle protein, increased hepatic acute-phase protein (APP) synthesis, and increased deamination of gluconeogenic amino acids $(A A)^{(1,3,4)}$. The acute-phase response is the early innate immune response to injury, trauma or infection, and increases serum concentrations of positive APP while decreasing concentrations of negative $\mathrm{APP}^{(5)}$. Synthesis of positive APP during an acutephase response is considered to be nutritionally more costly than the adaptive response to inflammation, i.e. leucocyte proliferation and antibody production ${ }^{(6)}$. Reeds et al $^{(7)}$ calculated $^{(7)}$ that an APP response increases the demand for aromatic AA in particular. For the synthesis of APP, AA are provided either from dietary protein or from the breakdown of skeletal muscle protein. The AA composition of APP differs, however, largely from that of muscle protein ${ }^{(7)}$, and from that of commercial diets, which are formulated mainly to enhance muscle protein deposition. It is hypothesised that, as a consequence, there can be an imbalance in available AA for body protein deposition, leading to increased oxidation of AA and $\mathrm{N}$ loss, which is close to the quantitative $\mathrm{N}$ loss observed in uncomplicated trauma ${ }^{(7)}$. Moreover, the cytokine-induced metabolic change after immune system activation generally results in increased breakdown and decreased synthesis of skeletal muscle protein ${ }^{(8,9)}$.

In pigs, immune system activation by continuous exposure to major vectors of antigen transmission ${ }^{(10)}$, or by intramuscular (i.m.) lipopolysaccharide (LPS) injection ${ }^{(11)}$ reduces feed

Abbreviations: AA, amino acids; Ad, adequate dietary protein supply; APP, acute-phase proteins; BW, body weight; CFA, complete Freund's adjuvant; CRP, C-reactive protein; Cys, cysteine; ECF, ethyl chloroformate ester; HAPI, health status acute-phase index; i.m., intramuscular; i.v., intravenous; Ile, isoleucine; ILR, irreversible loss rate; Leu, leucine; LPS, lipopolysaccharide; Lys, lysine; Met, methionine; MSPE, mean square prediction error; NAPI, nutritional acutephase index; Phe, phenylalanine; pigMAP, pig major acute-phase protein; Res, restricted dietary protein supply; Trp, tryptophan; TTR, tracer:tracee ratio; Tyr, tyrosine; Val, valine.

*Corresponding author: A. J. M. Jansman, email alfons.jansman@wur.nl 
intake, body-weight (BW) gain and $\mathrm{N}$ retention. Recent studies in pigs have revealed that immune system activation by i.m. LPS administration increases the optimal dietary Met:Met + cysteine (Cys) ratio ${ }^{(12)}$, and reduces the efficiency of Trp utilisation for body protein deposition ${ }^{(13)}$. These findings indicate that the utilisation for $\mathrm{AA}$ in growing pigs may change due to variation in health status. However, quantitative information about the effect of immune system activation on the utilisation for $\mathrm{AA}$ is lacking, and measurements on changes in responses of multiple AA simultaneously to immune system activation are largely absent. Alterations in AA metabolism, e.g. an increased protein synthesis rate, can occur without concomitant changes in plasma AA concentrations or pool size, as plasma AA concentrations can be maintained when AA fluxes alter by changes in dietary protein intake, breakdown and synthesis of body protein, and oxidation of $\mathrm{AA}^{(14)}$. The irreversible loss rate (ILR) of AA, reflects the amount of free AA that disappears per unit of time from the plasma pool for protein synthesis and oxidation. The combination of ILR measurements with $\mathrm{N}$ balance and pool size measurements can provide insight into the metabolic changes in multiple AA simultaneously. It is hypothesised that an increase in blood APP concentrations during immune system activation affects the utilisation of AA, associated with an increased incorporation of, in particular aromatic, AA into APP.

In the present study, intravenous (i.v.) administration of complete Freund's adjuvant (CFA), which has been previously shown to induce chronic lung inflammation in pigs ${ }^{(15,16)}$, was used to activate the immune system. It is hypothesised that the effect of a CFA challenge on protein metabolism is more pronounced under conditions of a marginal dietary protein supply, which would increase the competition for indispensable AA used for immune system functioning and for protein deposition in muscle as a main determinant of the animal's growth. In addition, there is increasing evidence that the dietary protein or AA supply can affect the inflammatory response during immune system activation ${ }^{(16-23)}$. A Trp-deficient diet, for instance, has been suggested to deteriorate the immune response to a CFA challenge, as indicated by increased indoleamine 2,3 dioxygenase (IDO) activity in the lungs and heart, and increased lung weight ${ }^{(16)}$ in contrast to a Trpsupplemented diet. As IDO is induced by cytokines ${ }^{(24)}$, its activity is associated with the degree of immune system activation. In another study, the addition of Cys to a proteindeficient diet increased liver weight and hepatic glutathione concentrations, following an intraperitoneal injection of TNF- $\alpha$ in rats ${ }^{(17)}$. The authors of the latter study have suggested that Cys supplementation improved the immune response following TNF- $\alpha$ administration, enabling a full metabolic response to cytokines that improves the ability to maintain antioxidant defences. Although it is debatable whether a change in immunological response is beneficial or not, these findings show that dietary protein or AA supply can affect the inflammatory response during immune system activation. The aim of the present study was to quantify the effect of immune system activation on $\mathrm{N}$ retention and $\mathrm{AA}$ metabolism in growing pigs, depending on dietary protein supply.

\section{Materials and methods}

\section{Animals and treatments}

The experiment was approved by the Animal Experimental Committee of Wageningen UR Livestock Research. A total of sixteen barrows (Dutch Landrace $\times$ York) with an initial BW of 28.5 (sem 0.5$) \mathrm{kg}$ were individually housed in metabolism cages $(1.3 \times 1.3 \mathrm{~m})$ at a room temperature ranging between 18 and $22^{\circ} \mathrm{C}$. Based on litter weight and BW, pigs were allocated to one of two treatment groups receiving either an adequate (Ad) or restricted (Res, 70\% of Ad) dietary protein supply at a similar daily supply of other nutrients. To this end, a basal mixture was designed without protein sources. The Ad diet included the basal mixture with the additional protein sources casein, wheat gluten meal, soya protein isolate and potato protein, and met the requirements for essential AA for growing pigs in the range of $35-45 \mathrm{~kg} \mathrm{BW}^{(25)}$ (Table 1). The Res diet included the basal mixture to which $70 \%$ of the quantities of additional protein sources (casein, wheat gluten meal, soya protein isolate and potato protein) were added compared with the quantities included in the $\mathrm{Ad}$ diet. In order to supply all pigs with the same amount of the basal mixture, relative to their metabolic $\mathrm{BW}$, the feed allowance of pigs assigned to the Res diet was $94.3 \%$ of that of pigs receiving the Ad diet. The experimental diets were provided in mash form and mixed with water using a feed:water ratio of 1:3. The pigs were fed at 07.00 and 15.30 hours in equal amounts at 2.7 times the energy requirements for maintenance $\left(458 \mathrm{~kJ}\right.$ metabolisable energy $/ \mathrm{kg} \quad \mathrm{BW}^{0.75}$ per $\mathrm{d}^{(26)}$ ). Feed refusals were collected $30 \mathrm{~min}$ after feeding.

At day -16 or -14 before the start of immune system activation, the pigs were surgically fitted with a jugular vein and a carotid artery catheter for blood collection and injection of a mixture of $\mathrm{U}^{1}{ }^{13} \mathrm{C}$-labelled AA, respectively. Neopen (Neomycin $5 \mathrm{mg} / \mathrm{kg}$ BW and Procaïne benzylpenicillin 10000 $\mathrm{IU} / \mathrm{kg} \mathrm{BW}$; Intervet) was given intramuscularly $1 \mathrm{~d}$ before surgery, at surgery and $1 \mathrm{~d}$ after surgery. Flunixin (Finadyne $2.2 \mathrm{mg} / \mathrm{kg}$ BW; Schering-Plough) was given intramuscularly at surgery and for $2 \mathrm{~d}$ after surgery. A timeline of the experiment is shown in Fig. 1, with day 0 being the start of immune system activation by the i.v. administration of CFA (F5881; Sigma-Aldrich). CFA is a mineral oil containing $1 \mathrm{mg}$ of dead Mycobacterium tuberculosis cells per $\mathrm{ml}$. The dose of CFA administered per pig was $0.2 \mathrm{ml} / \mathrm{kg} \mathrm{BW}$, diluted with saline in a ratio of 1:2. The dose was spread over four equal sub-doses, of which two were infused at day 0 and two at day 1 , in the morning between 09.15 and 10.30 hours, and in the afternoon between 15.15 and 16.30 hours. Of the pigs, eight did not receive the fourth sub-dose of CFA, as clinical observations after the first infusions on eight pigs showed a more severe response, i.e. greater and persistent feed refusals, and greater increase in respiratory rhythm, than expected based on a preliminary study (E Kampman-van de Hoek, unpublished results).

\section{Immunological response parameters}

At days $-5,-3,-1,3,4,5,6,7$ and 8 , blood samples were collected into serum tubes (Vacuette; Greiner Bio-One) and 
Table 1. Composition of the experimental diets (as-fed basis)

\begin{tabular}{|c|c|c|}
\hline & $\begin{array}{l}\text { Adequate- } \\
\text { protein diet }\end{array}$ & $\begin{array}{l}\text { Restricted- } \\
\text { protein diet }\end{array}$ \\
\hline \multicolumn{3}{|l|}{ Ingredient composition ( $\mathrm{g} / \mathrm{kg}$ ) } \\
\hline \multicolumn{3}{|l|}{ Basal mixture* } \\
\hline Wheat starch & $250 \cdot 0$ & 265.2 \\
\hline Pre-gelatinised potato starch & $240 \cdot 1$ & 254.7 \\
\hline Oat hulls & $100 \cdot 0$ & $106 \cdot 1$ \\
\hline Dextrose & $100 \cdot 0$ & $106 \cdot 1$ \\
\hline Beet pulp & $50 \cdot 0$ & $53 \cdot 0$ \\
\hline Soyabean oil & $30 \cdot 0$ & $31 \cdot 8$ \\
\hline Calcium carbonate & $15 \cdot 5$ & $16 \cdot 4$ \\
\hline Monocalcium phosphate & 11.6 & $12 \cdot 3$ \\
\hline Potassium carbonate & $6 \cdot 2$ & $6 \cdot 6$ \\
\hline $\mathrm{NaCl}$ & 3.9 & $4 \cdot 1$ \\
\hline Vitamin and mineral premix $\dagger$ & $2 \cdot 0$ & $2 \cdot 1$ \\
\hline \multicolumn{3}{|l|}{ Protein-containing ingredients } \\
\hline Soya protein isolate & $90 \cdot 0$ & $66 \cdot 8$ \\
\hline Casein & $65 \cdot 0$ & $48 \cdot 2$ \\
\hline Wheat gluten meal & 29.7 & $22 \cdot 1$ \\
\hline Potato protein $\ddagger$ & 5.3 & 3.9 \\
\hline DL-Met & 0.9 & 0.6 \\
\hline \multicolumn{3}{|l|}{ Calculated composition $(\mathrm{g} / \mathrm{kg}) \S$} \\
\hline DM & 927 & 927 \\
\hline NE $(M J / k g) \|$ & 10.55 & $10 \cdot 63$ \\
\hline Crude protein & 170 & 129 \\
\hline Crude ash & 51 & 52 \\
\hline Crude fat & 36 & 37 \\
\hline Crude fibre & 37 & 39 \\
\hline AID Lys & $9 \cdot 2$ & $6 \cdot 9$ \\
\hline AID Met & 3.9 & 2.9 \\
\hline AID Met + Cys & 5.5 & $4 \cdot 1$ \\
\hline AID Thr & 5.5 & $4 \cdot 1$ \\
\hline AID Trp & 1.8 & 1.3 \\
\hline AID lle & $7 \cdot 2$ & $5 \cdot 4$ \\
\hline AID His & $4 \cdot 1$ & $3 \cdot 1$ \\
\hline AID Leu & $13 \cdot 1$ & $9 \cdot 8$ \\
\hline AID Phe & $8 \cdot 1$ & $6 \cdot 1$ \\
\hline AID Val & $8 \cdot 1$ & $6 \cdot 0$ \\
\hline \multicolumn{3}{|l|}{ Analysed composition ( $\mathrm{g} / \mathrm{kg}$ ) } \\
\hline Crude protein & 182 & 137 \\
\hline Total Lys & $11 \cdot 2$ & 8.5 \\
\hline Total Met & $4 \cdot 1$ & 3.0 \\
\hline Total Met + Cys & 5.8 & 4.4 \\
\hline Total Thr & $6 \cdot 7$ & $5 \cdot 2$ \\
\hline Total Trp & $2 \cdot 0$ & 1.6 \\
\hline Total lle & $8 \cdot 2$ & $6 \cdot 3$ \\
\hline Total His & 4.6 & 3.6 \\
\hline Total Leu & 14.9 & 11.4 \\
\hline Total Phe & $9 \cdot 2$ & $7 \cdot 1$ \\
\hline Total Val & $9 \cdot 7$ & $7 \cdot 4$ \\
\hline
\end{tabular}

$\mathrm{NE}$, net energy; AID, apparent ileal digestible.

* Two levels of dietary protein supply (adequate or restricted ( $70 \%$ of adequate)) were used in the study, at a similar daily supply of other nutrients. In the restricted dietary protein supply, the proportion of protein-containing ingredients in the diet was reduced by $30 \%$ relative to the proportion in the adequate-protein diet. In order to supply all pigs with the same amount of the basal mixture, relative to their metabolic body weight, the feed allowance of pigs fed the restricted-protein diet was $94.3 \%$ of those fed the adequate-protein diet.

†Vitamin and mineral premix provided per $\mathrm{kg}$ of adequate or restricted diet, respectively: 2.4 or $2.5 \mathrm{mg}$ vitamin A; 50 or $52.5 \mu \mathrm{g}$ cholecalciferol; 14.7 or $15.7 \mathrm{mg}$ vitamin $\mathrm{E} ; 1.5$ or $1.6 \mathrm{mg}$ vitamin $\mathrm{K} ; 1.0$ or $1.1 \mathrm{mg}$ thiamin; 4.0 or $4.2 \mathrm{mg}$ riboflavin; 12.0 or $12.6 \mathrm{mg}$ pantothenic acid; 20.0 or $21.0 \mathrm{mg}$ niacin; 20.0 or $21.0 \mu \mathrm{g}$ vitamin $\mathrm{B}_{12} ; 0.20$ or $0.21 \mathrm{mg}$ folate; 1.0 or $1.1 \mathrm{mg}$ vitamin $\mathrm{B}_{6} ; 100$ or $105 \mathrm{mg}$ choline chloride; 100 or $105 \mathrm{mg} \mathrm{Fe}$ as $\mathrm{FeSO}_{4} ; 10.0$ or $10.5 \mathrm{mg} \mathrm{Cu}$ as CuSO4.5 $\mathrm{H}_{2} \mathrm{O} ; 65.0$ or $68.3 \mathrm{mg} \mathrm{Zn}$ as $\mathrm{ZnO} ; 30.0$ or $31.5 \mathrm{mg} \mathrm{Mn}$ as $\mathrm{MnO}$; 0.15 or $0.16 \mathrm{mg}$ Co as $\mathrm{CoSO}_{4} ; 0.75$ or $0.79 \mathrm{mg} \mathrm{K}$ as KI; 0.30 or $0.31 \mathrm{mg}$ Se as sodium selenite.

$\ddagger$ Protastar $^{\circledR}$, AVEBE Feed

$\S$ Unless indicated otherwise.

$\| N E$ was calculated based on Centraal Veevoederbureau ${ }^{(59)}$. allowed to clot for $1 \mathrm{~h}$ at room temperature. Serum was collected after centrifugation for $10 \mathrm{~min}$ at $1800 \mathrm{~g}$ and was stored at $-20^{\circ} \mathrm{C}$ until analyses of albumin (Randox Bromocresol Green assay, catalogue no. AB 362), C-reactive protein (CRP, ELISA; Reactivlab Limited), haptoglobin (Tridelta Phase Haptoglobin Assay, catalogue no. TP-801), pig major APP (pigMAP, ELISA; Reactivlab Limited), and total protein (biuret reaction $^{(27)}$ ). At days $-5,0,1,3,5$ and 8 , blood samples were collected into EDTA tubes (Vacuette; Greiner Bio-One) and analysed for the number of total leucocytes. At day 9, all pigs were euthanised and autopsy was performed by an experienced pathologist. Autopsy observations included assessment of body condition, visual inspection for abnormalities of the lungs, spleen, stomach, small intestine, large intestine, kidneys, liver, heart, and mesenteric lymph nodes, determination of lung weight, and histological evaluation of the lungs, liver, tracheobronchial lymph nodes and kidneys.

\section{Nitrogen balance}

Pigs were equipped with a Velcro support system to allow separate collection of the faeces ${ }^{(28)}$ and urine. Faeces and urine were collected quantitatively from each pig during two periods of five subsequent days each, i.e. in the pre- and post-challenge periods (Fig. 1). Faeces were stored at $-20^{\circ} \mathrm{C}$ until analysis. Urine was collected via funnels, which were sprayed with an acetic acid buffer (sodium acetate $0.08 \mathrm{~m}$, formic acid 0.025 $\mathrm{M}$ and acetic acid $0.013 \mathrm{M}$ ) to prevent evaporation of $\mathrm{NH}_{3}$, into buckets containing sulphuric acid $(4.5 \mathrm{M})$, to maintain a $\mathrm{pH}<3$ for conservation. Urine was collected daily from the buckets, weighed, sampled and stored at $-20^{\circ} \mathrm{C}$ until analysis. $\mathrm{N}$ content in the urine and fresh faeces was analysed using the Kjeldahl method ${ }^{(29)}$. DM content of the faeces was determined by drying at $103^{\circ} \mathrm{C}^{(30)}$.

\section{Amino acid metabolism}

At pre-challenge (day -5), early post-challenge (day 3) and late post-challenge (day 8), the fluxes of plasma lysine, tryptophan, methionine, isoleucine, leucine, valine, phenylalanine and tyrosine (Lys, Trp, Met, Ile, Leu, Val, Phe and Tyr, respectively) were studied by measuring the change in plasma isotopic enrichment of individual AA in time after an intravenously administered bolus of these $\mathrm{U}^{13} \mathrm{C}$-labelled AA. To create a steady state in dietary AA supply at the day of injection of the $\mathrm{U}-{ }^{13} \mathrm{C}$-labelled AA mixture and frequent blood sampling, daily feed allowance was spread over ten equal meals. Of these, two meals were fed at 07.30 hours, followed by hourly meals from 09.10 hours until 16.10 hours. At 12.30 hours, a mixture of eleven $\mathrm{U}^{13}{ }^{13} \mathrm{C}$-labelled AA (97-99 atom percent ${ }^{13} \mathrm{C}$; Cambridge Isotope Laboratories) was injected. The composition of the mixture ( $\mathrm{mg} / \mathrm{g}$ saline) was as follows: L-Lys, 0.17; L-Thr, 0.18; L-Trp, 0.07; L-Met, 0.06; L-Cys, 0.04; L-Ile, 0·16; L-Leu, 0·16; L-Val, 0·19; L-Phe, 0·13; L-Tyr, 0·16; L-histidine, 0.08 . The mixture was injected as a bolus $(0.50 \mathrm{~g} / \mathrm{kg}$ BW; $0.25 \mathrm{ml} / \mathrm{s}$ ) in the carotid artery. If the carotid artery catheter was blocked, the mixture was injected in the jugular vein. Blood samples $(4 \mathrm{ml}$ each) were collected from the jugular 


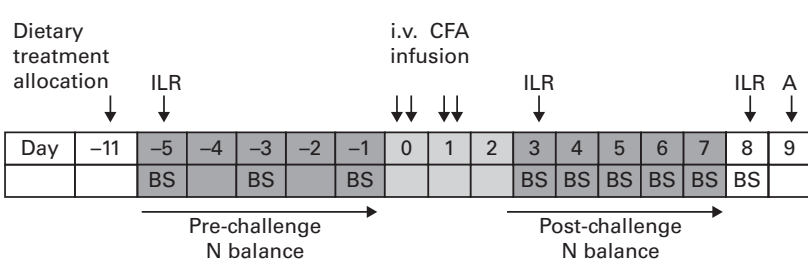

Fig. 1. Timeline of the experimental period. A, autopsy; BS, blood sampling; $\mathrm{ILR}$, irreversible loss rate measurement by the injection of the $\mathrm{U}-{ }^{13} \mathrm{C}$-labelled amino acid mixture; i.v., intravenous; CFA, complete Freund's adjuvant.

vein and transferred into tubes containing lithium heparin (Vacuette; Greiner Bio-One) at $10 \mathrm{~min}$ before the injection of the U- ${ }^{13} \mathrm{C}$-labelled AA mixture and at 3, 5, 7, 9, 11, 15, 25, 45,80 and $120 \mathrm{~min}$ after injection. The tubes were immediately placed on ice and centrifuged for $10 \mathrm{~min}$ at $2000 \mathrm{~g}$ at $4^{\circ} \mathrm{C}$, after which plasma was collected and stored at $-20^{\circ} \mathrm{C}$ until analysis. In each blood sample, ${ }^{13} \mathrm{C}$ enrichment was measured in plasma Lys, Trp, Met, Ile, Leu, Val, Phe and Tyr as ethyl chloroformate ester (ECF; Merck Schuchardt OHG) derivatives by GC-combustion-isotope ratio MS (Isotope Ratio MS, Delta V Advantage, Thermo Scientific; GC Trace Ultra, Thermo Scientific (column no. CP8982, VF- $17 \mathrm{~ms} 30 \mathrm{~m} \times 0.25 \mathrm{~mm}$, film $0.25 \mu \mathrm{m}$; Agilent Technologies); and combustion, Combustion III, Thermo Scientific), as adapted from Huang et al. ${ }^{(31)}$. Briefly, $20 \mu \mathrm{l}$ hydrogen chloride (1 M) and $200 \mu$ l Dowex ion exchange resin (AG 50W-X8 $\mathrm{H}^{+}$form, 200-400 mesh; Dow Chemical Company) were added to $180 \mu \mathrm{l}$ plasma and eluted with $0.7 \mathrm{ml}$ ammonium hydroxide $(6 \mathrm{~m})$ to isolate free plasma AA. The supernatant was evaporated with a centrifugal concentrator (Jouan RC 1022; Thermo Scientific) under vacuum at room temperature. Derivatisation was performed by adding $140 \mu \mathrm{l}$ ethanol-pyridine (4:1, v/v) and $20 \mu \mathrm{l} \mathrm{ECF}$ to the dry supernatant. Derivates were extracted by adding $4 \times 200 \mu$ l hexane-dichloromethane-ECF (50:50:1, by vol.), and the supernatant was dried in a vial under $\mathrm{N}_{2}$ gas at room temperature. After dissolving in $50 \mu$ l ethyl acetate, the sample was injected in triplicate into the GC. The ${ }^{13} \mathrm{C}$ enrichment of histidine could not be successfully analysed due to high losses of histidine during the derivatisation step. The ${ }^{13} \mathrm{C}$ enrichment of $\mathrm{Thr}$ and Cys could not be determined with the current procedure, and additional derivatisation steps would be required for their measurement.

\section{Calculations}

Dietary $\mathrm{N}$ intake, faecal and urinary $\mathrm{N}$ excretion and wholebody $\mathrm{N}$ retention were expressed relative to metabolic BW $\left(\mathrm{kg} \mathrm{BW}{ }^{075}\right)$. Relative lung weight was calculated as a percentage of BW. ${ }^{13} \mathrm{C}$ enrichment in plasma AA was expressed as the tracer:tracee ratio (TTR). To calculate a change in the TTR in time, for each AA, the background enrichment (obtained from plasma samples taken before the injection of the $\mathrm{U}_{-}{ }^{13} \mathrm{C}$-labelled AA mixture) was subtracted from ${ }^{13} \mathrm{C}$ enrichment in samples after injection.

The ILR of AA from plasma was calculated from the change in the ${ }^{13} \mathrm{C}$ enrichment of plasma $\mathrm{AA}$ after the intravenously administered bolus of $\mathrm{U}_{-}{ }^{13} \mathrm{C}$-labelled AA using the model and calculations as described by Holtrop et al. ${ }^{(32)}$. The following assumptions were made: there is a physiological steady state during the measurement, i.e. a constant size of the plasma AA pool, so that the inflow of AA into the plasma pool equals the outflow from the plasma pool ${ }^{(14)}$; the tracer transfers along with the tracee between compartments with a constant fractional rate ${ }^{(14)}$; the ILR for an AA occurs as an output from the plasma pool, and only by the incorporation of the AA into synthesised protein or by the loss of the AA via oxidation ${ }^{(33)}$. Finally, once the tracer has entered the body protein pool, there is no recycling of the tracer into the plasma pool, as the whole-body protein pool is a large pool with a low turnover rate compared with the plasma pool ${ }^{(14)}$. A double exponential model was fitted to the ${ }^{13} \mathrm{C}$ enrichment of individual plasma AA after the administration of the bolus injection:

$$
E(t)=a_{1} \exp \left(b_{1} t\right)+a_{2} \exp \left(b_{2} t\right),
$$

where $E(t)$ is the predicted ${ }^{13} \mathrm{C}$ enrichment in plasma AA (TTR) at time $t(\mathrm{~min})$; and $a_{1}, b_{1}, a_{2}$ and $b_{2}$ are parameter estimates from which the ILR ( $\mu \mathrm{mol} / \mathrm{kg}$ BW per h) was calculated:

$$
\operatorname{ILR}=d /\left(a_{1} / b_{1}+a_{2} / b_{2}\right) 60
$$

where $d$ is the dose of the administered $\mathrm{U}^{13} \mathrm{C}$-labelled AA ( $\mu \mathrm{mol} / \mathrm{kg} \mathrm{BW}$ ).

For each AA and pig, the pool size, i.e. the amount of AA in the pool $(\mu \mathrm{mol} / \mathrm{kg} \mathrm{BW})$, was calculated as:

$$
\text { Pool size }=d 0 /\left(a_{1}+a_{2}\right) \text {. }
$$

An ILR index was calculated for each pig and time point as the ILR at day $-5,3$ or 8 divided by the mean ILR at days -5 , 3 and 8 of that particular pig, multiplied by 100. This index indicates the change in the ILR within animals as affected by the challenge.

AA released from protein breakdown was calculated as the difference between the ILR and dietary intake, using the steady-state model of Waterlow ${ }^{(14)}$, i.e. ILR $=$ protein breakdown + dietary intake $=$ protein synthesis + AA oxidation. Intake was estimated by multiplying the feed intake by the dietary apparent ileal digestible content of each AA and divided by $24 \mathrm{~h}$ and the molar mass.

The following two indices were calculated from serum concentrations of APP: a nutritional acute-phase index (NAPI), and a health status acute-phase index (HAPI). The NAPI was considered to be associated with the nutritional costs of APP synthesis, implying that the half-lives of the APP should be taken into account. The half-life of a positive APP was considered to be inversely related to the requirements for AA for APP synthesis. To amplify the nutritional costs of an APP response, all the measured positive APP are divided by the half-life (CRP $19 \mathrm{~h}^{(34)}$, haptoglobin $132 \mathrm{~h}^{(35)}$ and pigMAP $132 \mathrm{~h}$, with the latter value being assumed to be similar to that of haptoglobin, based on the response pattern $\left.{ }^{(36)}\right)$ :

$$
\begin{aligned}
\mathrm{NAPI}= & (\text { pigMAP }(\mathrm{g} / \mathrm{l}) / \text { half-life })+(\mathrm{CRP}(\mathrm{g} / \mathrm{l}) / \text { half-life }) \\
& +(\text { haptoglobin }(\mathrm{g} / \mathrm{l}) / \text { half-life })
\end{aligned}
$$


The HAPI was calculated as the sum of positive APP indices divided by the index for albumin as a negative APP, in which each index reflects the change in APP within a pig relative to the mean APP at days $-5,3$ and 8 of that pig. The HAPI was considered as a general indicator of health status. By including the indices for positive and negative APP in the HAPI, the range in values is amplified ${ }^{(37,38)}$ :

$$
\mathrm{HAPI}=\frac{\mathrm{CRP} \text { index }+ \text { haptoglobin index }+ \text { pigMAP index }}{\text { albumin index }}
$$

where the APP index (e.g. CRP index) was calculated for each pig and time point as the APP concentration at days $-5,3$ or 8 divided by the mean APP concentration at days $-5,3$ and 8 of that particular pig, multiplied by 100 .

\section{Statistical analysis}

Pig was considered as the experimental unit. The effects of dietary treatment and collection day or period on leucocytes, $\mathrm{N}$ balance measures, ILR, AA release in plasma from protein breakdown, and AA plasma pool size were analysed with a mixed model, with collection day, or period, taken as the repeated measure. Fixed effects also included the interaction between dietary treatment and collection day, or period. The effects were analysed by pairwise comparisons using Tukey-Kramer adjustment. A covariance structure was chosen based on the lowest value for the Akaike and Bayesian information criteria. The effects of dietary treatment, collection day and the interaction between the two on APP and total protein serum concentrations were analysed separately per period (pre- and post-challenge) with a mixed model, with collection day taken as the repeated measure. For the post-challenge APP serum concentrations, the mean of prechallenge serum APP concentrations (days $-5,-3$ and -1 ) was used as a covariate. The effect of dietary treatment on relative lung weight was analysed by ANOVA. To associate a change in AA utilisation with a change in APP concentrations or $\mathrm{N}$ balance, the correlation between the ILR index for AA and the NAPI or HAPI, and the correlation between $\mathrm{N}$ retention and the ILR or ILR index were determined using a Pearson correlation analysis. To distinguish between the $2 \mathrm{~d}$ post-challenge (days 3 and 8 ), the correlation analyses were performed separately in two parts, i.e. including data of pre-challenge and day 3 post-challenge, and including data of pre-challenge and day 8 post-challenge.

The normality of the distribution of studentised residuals was assessed. Data on pigMAP and CRP were log transformed to obtain the normal distribution of model residuals. All statistical procedures were conducted in SAS (SAS Institute, Inc.). Data are presented as means with their pooled standard errors, and the effects were considered significant at $P \leq 0.05$.

The goodness-of-fit of the double exponential model used to fit the ${ }^{13} \mathrm{C}$ enrichment of individual plasma AA was assessed by the mean square prediction error (MSPE). The root MSPE was scaled to the observed mean (mean prediction error), and the correlation between the predicted and observed values was calculated. Errors due to overall bias, due to the deviation of the regression slope from unity, and due to random variation were calculated ${ }^{(39)}$. Enrichment data of some AA were excluded due to unrealistic parameter estimation and concomitant unrealistic ILR.

\section{Results}

During the post-challenge measurement period, four pigs had feed refusals that exceeded $10 \%$ of their daily allowance. Data from these pigs were excluded from the experiment. Subsequently, one pig was excluded from the experiment due to illness occurring before the start of the $\mathrm{N}$ balance measurements.

\section{Immunological response}

At pre-challenge, serum CRP concentrations were lower $(P=0.02)$ in Res-pigs than in Ad-pigs. In the pre-challenge period, dietary protein supply did not affect serum concentrations of haptoglobin, pigMAP and total protein. In the pre- and post-challenge periods, Res-pigs tended to have lower $(P=0.09)$ serum albumin concentrations than Ad-pigs. In the post-challenge period, dietary protein supply did not affect serum concentrations of CRP, haptoglobin, pigMAP and total protein.

In the pre-challenge period, serum albumin concentrations were higher $(P=0.007)$ at day -5 than at days -3 and -1 (Fig. 2). In the post-challenge period, collection day affected serum concentrations of all APP and total protein. Serum concentrations of CRP peaked at day 5 post-challenge $(P<0 \cdot 001)$ and declined thereafter. Serum concentrations of haptoglobin peaked at day $3(P<0 \cdot 001)$ and declined thereafter. Serum concentrations of pigMAP peaked at day $3(P<0.001)$ and declined thereafter (Fig. 2). Serum concentrations of albumin $(P=0.001)$ and total protein $(P=0.002)$ showed a drop at day 4 .

Leucocyte counts were unaffected by dietary protein supply. The leucocyte count was lower at day 1 post-challenge $(P=0.03)$ than at day -5 pre-challenge and day 8 post-challenge (Fig. 2). The leucocyte count was lower at day 0 pre-challenge $(P=0.03)$ than at day 8 post-challenge (Fig. 2).

Autopsy results revealed that intravenously administered CFA induced a moderate to severe granulomatous interstitial pneumonia. The relative lung weight was 1.52 (SEM $0 \cdot 10$ ) \% of BW at day 9 post-challenge, and was unaffected by dietary protein supply. Overall, six pigs showed signs of lymphohistiocytic focal hepatitis, and one pig showed signs of lymphocytosis. In one pig, sinus histiocytosis was observed in the tracheobronchial lymph nodes. No abnormalities were found in the other organs.

\section{Performance and nitrogen retention}

Dietary protein supply did not affect faecal N excretion. Totaltract $\mathrm{N}$ digestibility was greater in Ad-pigs than in Res-pigs $(P=0.001)$. Urinary $\mathrm{N}$ excretion was greater in Ad-pigs than in Res-pigs $(P<0 \cdot 001)$, and $\mathrm{N}$ retention was $20 \%$ lower in 

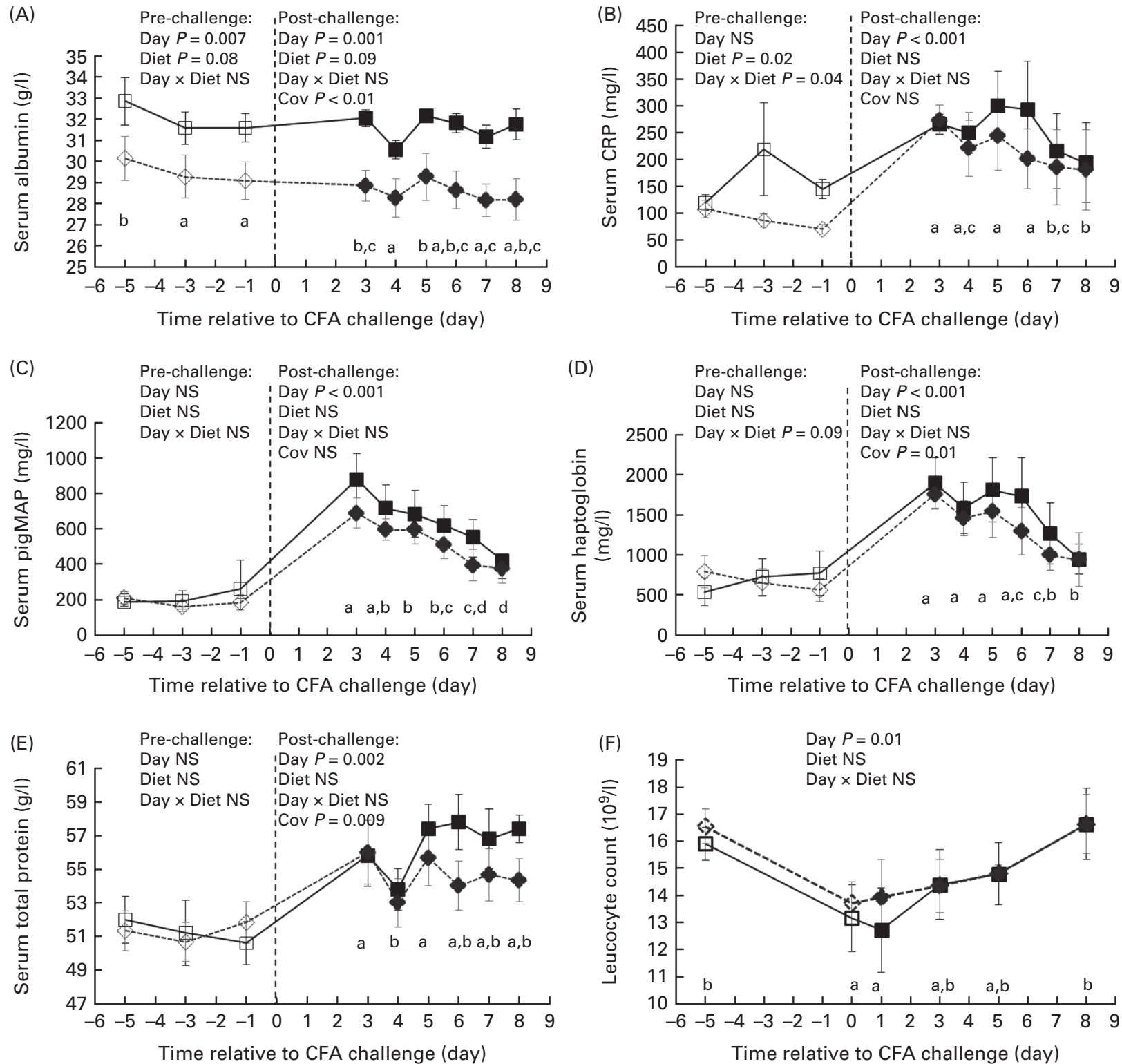

Fig. 2. Effect of complete Freund's adjuvant (CFA) challenge and dietary protein supply (adequate $(\square, \boldsymbol{\square})$ or restricted $(\diamond$, $\diamond)$ ) on serum acute-phase proteins (APP: albumin (A); C-reactive protein (CRP) (B); pig major APP (pigMAP) (C); haptoglobin (D)), serum total protein concentrations (E) and leucocyte count (F) in growing pigs $(n 11)$. Open and closed symbols indicate pre- and post-challenge measures, respectively. Values are means, with their standard errors represented by vertical bars. $\mathrm{a}, \mathrm{b}, \mathrm{c}, \mathrm{d}$ Within the pre- or post-challenge period, mean values with unlike letters were significantly different $(P<0.05$; effect of day). Covariate, in the analysis of post-challenge APP serum concentrations, the mean of pre-challenge APP concentrations (days $-5,-3$ and -1 ) was used as a covariate.

Res-pigs than in Ad-pigs $(P<0 \cdot 001)$. N utilisation for retention was greater in Res-pigs $(P=0.02)$ than in Ad-pigs (Table 2$)$. The CFA challenge did not affect $\mathrm{N}$ intake, faecal $\mathrm{N}$ excretion and apparent total-tract $\mathrm{N}$ digestibility (Table 2). Urinary $\mathrm{N}$ excretion was greater at post-challenge than at pre-challenge $(P=0 \cdot 04)$. N retention $(P=0 \cdot 07)$ and $\mathrm{N}$ utilisation for retention $(P=0.07)$ tended to be greater in the pre- than in the post-challenge period.

\section{Amino acid metabolism}

The double exponential model accurately described the decrease in the ${ }^{13} \mathrm{C}$ enrichment of individual plasma AA after the injection of the bolus with ${ }^{13} \mathrm{C}$-labelled AA. The average root MSPE of the studied AA ranged between 4.8 and $6.9 \%$, with $>95 \%$ of the prediction error attributable to random variation.

Res-pigs had a lower ILR for Lys $(P=0 \cdot 02)$, Met $(P=0 \cdot 03)$, Ile $(P=0.05)$, Val $(P<0 \cdot 01)$ and Tyr $(P<0 \cdot 01)$ than Ad-pigs, and tended to have a lower ILR for Phe $(P=0.09)$. The ILR for Leu and Trp was not affected by dietary protein supply. Res-pigs had a lower Lys $(P=0.03)$, Val $(P=0.02)$ and $\mathrm{Tyr}$ $(P=0.03)$ release from protein breakdown than Ad-pigs, and the Met release from protein breakdown tended to be lower in Res-pigs $(P=0 \cdot 06)$. The Trp, Ile, Leu and Phe release from protein breakdown was not affected by dietary protein 
Table 2. Effect of complete Freund's adjuvant challenge and dietary protein supply (adequate or restricted) on growth performance and nitrogen balance in growing pigs

(Mean values with their pooled standard errors)

\begin{tabular}{|c|c|c|c|c|c|c|c|c|}
\hline \multirow{2}{*}{$\begin{array}{l}\text { Diet } \\
\text { Challenge }\end{array}$} & \multicolumn{2}{|c|}{ Adequate } & \multicolumn{2}{|c|}{ Restricted } & \multirow[b]{2}{*}{ SEM } & \multicolumn{3}{|c|}{$P$} \\
\hline & Pre & Post & Pre & Post & & Challenge & Diet & Challenge $\times$ diet \\
\hline$n$ & 5 & 5 & 6 & 6 & & & & \\
\hline $\mathrm{BW}(\mathrm{kg})^{\star}$ & 38.9 & $44 \cdot 3$ & $37 \cdot 0$ & $40 \cdot 6$ & 0.83 & - & - & - \\
\hline $\mathrm{N}$ digestibility (\%) & $94 \cdot 7$ & 94.9 & 92.4 & 93.1 & 0.28 & 0.14 & 0.001 & 0.27 \\
\hline $\mathrm{N}$ balance $\left(\mathrm{g} / \mathrm{kg} \mathrm{BW} \mathrm{BW}^{0.75}\right.$ per $\left.\mathrm{d}\right)$ & & & & & & & & \\
\hline $\mathrm{N}$ intake & $2 \cdot 32$ & 2.32 & 1.77 & 1.75 & 0.061 & $0 \cdot 17$ & $<0.001$ & 0.23 \\
\hline Faecal $\mathrm{N}$ excretion & 0.12 & 0.12 & 0.13 & 0.12 & 0.003 & $0 \cdot 16$ & 0.41 & 0.34 \\
\hline Urinary $\mathrm{N}$ excretion & 0.64 & 0.73 & 0.42 & 0.43 & 0.031 & 0.04 & $<0.001$ & 0.14 \\
\hline $\mathrm{N}$ retention & 1.57 & 1.47 & 1.22 & 1.20 & 0.038 & 0.07 & $<0.001$ & 0.28 \\
\hline $\mathrm{N}$ retention/digestible $\mathrm{N}$ intake (\%) & $71 \cdot 2$ & $66 \cdot 9$ & 74.6 & 73.3 & 0.96 & 0.07 & 0.02 & 0.29 \\
\hline
\end{tabular}

BW, body weight.

${ }^{*}$ Average BW based on measurements at $1 \mathrm{~d}$ before the start of each $\mathrm{N}$ balance period and at the last day of the $\mathrm{N}$ balance period.

supply. Lys pool size tended $(P=0 \cdot 08)$ to be lower in Res-pigs than in Ad-pigs (Table 3).

The ILR for Val was affected by day of collection $(P=0 \cdot 04)$; it remained constant until $3 \mathrm{~d}$ post-challenge, but was $7 \%$ lower $(P=0.05)$ at day 8 post-challenge (Table 3$)$. The ILR for Tyr tended to be affected by day of collection $(P=0 \cdot 06)$, with a $9 \%$ lower $(P=0.06)$ ILR at day 8 post-challenge than at day -5 pre-challenge. Val release in plasma from protein breakdown tended to be affected by day of collection $(P=0 \cdot 10)$, with a $6 \%$ lower $(P=0.09)$ breakdown rate at day 8 post-challenge than at day 3 post-challenge. Tyr release from protein breakdown tended to be affected by day of collection $(P=0.09)$, with a $10 \%$ lower $(P=0.09)$ breakdown rate at day 8 post-challenge than at pre-challenge. The pool size of Lys, Trp, Ile, Leu, Val, Phe and Tyr was not affected by day of collection. The Met pool size was about $230 \%$ greater at day 8 than at day 3 post-challenge in Ad-pigs, but not in Res-pigs $(P=0 \cdot 03$; Table 3$)$.

\section{Correlations between irreversible loss rate v. nutritional acute-phase index, health status acute-phase index and nitrogen retention}

The results of the correlation analyses between the ILR or the ILR index of AA and the NAPI, HAPI or N retention are presented in Table 4. The ILR index was not affected by dietary protein supply. Positive correlations were observed between the ILR and $\mathrm{N}$ retention for all AA, except for Trp. The ILR of the sum of all measured AA was positively correlated with $\mathrm{N}$ retention. The ILR index did not correlate with $\mathrm{N}$ retention for any of the AA measured.

\section{Discussion}

The aim of the present study was to quantify the effect of immune system activation on $\mathrm{N}$ retention and AA metabolism in growing pigs, depending on dietary protein supply.

The i.v. administration of CFA has been previously used in pigs as a model for immune system activation ${ }^{(15,40,41)}$. In the present study, i.v. CFA administration activated the innate immune system, as indicated by a 2- to 4-fold increase in serum concentrations of CRP, haptoglobin and pigMAP. The observed increase in haptoglobin concentration is in accordance with a study of Melchior et al. ${ }^{(40)}$ in CFAchallenged pigs. Similarly, haptoglobin and pig-MAP concentrations increase up to 6-fold and CRP concentrations up to 4-fold in response to bacterial and parasitic infections, or inflammation induced by subcutaneous turpentine challenge in pigs $^{(42)}$. The observed reduction in leucocytes at day 1 post-challenge might be due to leucocyte migration into the lungs, as infiltration of neutrophils and eosinophils has been reported in lung tissue after i.v. CFA administration in pigs ${ }^{(41)}$. Autopsy results in the present study also indicate increased infiltration of lymphocytes and macrophages in the lungs and liver following the CFA challenge. The drop in leucocytes at day 0 pre-challenge was, however, unexpected.

In the present study, dietary protein supply did not affect the relative lung weight of the pigs following CFA administration. In contrast, Le Floc'h et al. ${ }^{(16)}$ observed greater lung weight in CFA-challenged pigs fed a Trp-deficient diet than in pigs fed an adequate-Trp diet. In the present study, the restricted dietary protein supply reduced pre-challenge serum CRP concentrations and tended to reduce serum albumin concentrations pre- and post-challenge. In line with the present results, plasma albumin concentrations, and albumin fractional and absolute synthesis rates decreased in pigs ${ }^{(18)}$ fed low-protein diets and after subcutaneous turpentine challenge. In addition, a lower plasma albumin concentration and albumin fractional synthesis rate was observed in intramuscularly LPS-challenged pigs fed a low-Met + Cys diet than in pigs fed a diet with an adequate Met + Cys content ${ }^{(43)}$. These findings may suggest that dietary AA supply can be insufficient for albumin synthesis, independent of immune system activation. Albumin serves as a nutrient carrier and depot by binding to nutrients ${ }^{(44,45)}$. This carrying capacity is possibly reduced when dietary protein supply is restricted. Houdijk et al. ${ }^{(46)}$ found a reduction in plasma CRP concentrations when the dietary protein content decreased in pigs with subclinical colibacillosis. The present results indicate that serum CRP concentrations are sensitive to dietary protein supply in the absence of immune system activation. Upon immune system activation, however, serum CRP concentrations were unaffected by 
Table 3. Effect of complete Freund's adjuvant challenge and dietary protein supply (adequate or restricted) on the irreversible loss rate (ILR, $\mu \mathrm{mol} / \mathrm{kg}$ body weight (BW) per $\mathrm{h}$ ), release from protein breakdown ( $\mu \mathrm{mol} / \mathrm{kg}$ BW per $\mathrm{h}$ ) and pool size ( $\mu \mathrm{mol} / \mathrm{kg} \mathrm{BW})$ of plasma amino acids $(\mathrm{AA})$ in growing pigs

(Mean values with their pooled standard errors)

\begin{tabular}{|c|c|c|c|c|c|c|c|c|c|c|}
\hline \multirow{2}{*}{$\begin{array}{l}\text { Diet ... } \\
\text { Day (pre- or post-challenge) ... }\end{array}$} & \multicolumn{3}{|c|}{ Adequate } & \multicolumn{3}{|c|}{ Restricted } & \multirow[b]{2}{*}{ SEM } & \multicolumn{3}{|c|}{$P$} \\
\hline & Pre day -5 & Post day 3 & Post day 8 & Pre day -5 & Post day 3 & Post day 8 & & Day & Diet & Day $\times$ diet \\
\hline Lys $(n)$ & 5 & 5 & 5 & 4 & 6 & 6 & & & & \\
\hline ILR & 695 & 716 & 698 & 559 & 605 & 576 & $18 \cdot 2$ & 0.61 & 0.02 & 0.95 \\
\hline Breakdown* & 625 & 648 & 631 & 510 & 556 & 528 & $17 \cdot 2$ & 0.60 & 0.03 & 0.96 \\
\hline Pool size & 85 & 79 & 108 & 90 & 74 & 53 & 6.6 & 0.88 & 0.08 & 0.23 \\
\hline $\operatorname{Trp}(n)$ & 4 & 4 & - & 4 & 6 & 1 & & & & \\
\hline ILR & 83 & 77 & - & 87 & 70 & 63 & $3 \cdot 2$ & 0.27 & 0.80 & 0.49 \\
\hline Breakdown & 71 & 65 & - & 78 & 62 & 55 & $3 \cdot 2$ & 0.28 & 0.69 & 0.48 \\
\hline Pool size & 16 & 16 & - & 22 & 14 & 27 & 1.4 & 0.13 & 0.39 & 0.27 \\
\hline Met $(n)$ & 5 & 5 & 4 & 4 & 6 & 4 & & & & \\
\hline ILR & 271 & 267 & 295 & 221 & 237 & 198 & $10 \cdot 1$ & 0.91 & 0.03 & 0.21 \\
\hline Breakdown & 235 & 232 & 261 & 196 & 212 & 174 & 9.6 & 0.91 & 0.06 & 0.21 \\
\hline Pool size & 42 & $27^{\mathrm{a}}$ & $88^{b}$ & 36 & 39 & 24 & 6.4 & 0.24 & 0.16 & $0.03 \dagger$ \\
\hline Ile $(n)$ & 5 & 5 & 5 & 5 & 6 & 6 & & & & \\
\hline ILR & 450 & 464 & 426 & 400 & 400 & 379 & 9.9 & 0.24 & 0.05 & 0.86 \\
\hline Breakdown & 374 & 390 & 354 & 346 & 347 & 328 & 9.0 & 0.29 & 0.21 & 0.85 \\
\hline Pool size & 85 & 73 & 78 & 84 & 75 & 55 & $5 \cdot 8$ & 0.57 & 0.46 & 0.73 \\
\hline Leu $(n)$ & 5 & 5 & 5 & 5 & 6 & 6 & & & & \\
\hline ILR & 797 & 744 & 732 & 690 & 612 & 633 & $25 \cdot 9$ & 0.33 & 0.13 & 0.92 \\
\hline Breakdown & 658 & 610 & 601 & 592 & 516 & 539 & 24.5 & 0.37 & 0.30 & 0.92 \\
\hline Pool size & 136 & 89 & 106 & 118 & 92 & 87 & $9 \cdot 6$ & 0.32 & 0.57 & 0.88 \\
\hline Val $(n)$ & 5 & 5 & 5 & 5 & 6 & 6 & & & & \\
\hline ILR & 632 & 655 & 600 & 548 & 550 & 520 & 11.9 & 0.04 & $<0.01$ & 0.74 \\
\hline Breakdown & 536 & 562 & 509 & 481 & 484 & 455 & $10 \cdot 2$ & 0.10 & 0.02 & 0.73 \\
\hline Pool size & 150 & 135 & 138 & 142 & 128 & 93 & $9 \cdot 1$ & 0.49 & 0.19 & 0.70 \\
\hline Phe $(n)$ & 5 & 5 & 5 & 5 & 5 & 6 & & & & \\
\hline ILR & 318 & 312 & 309 & 269 & 266 & 268 & 8.8 & 0.87 & 0.09 & 0.99 \\
\hline Breakdown & 250 & 246 & 245 & 220 & 219 & 221 & 8.0 & 0.94 & 0.30 & 1.00 \\
\hline Pool size & 59 & 57 & 63 & 57 & 58 & 60 & 4.5 & 0.94 & 0.84 & 0.98 \\
\hline $\operatorname{Tyr}(n)$ & 5 & 5 & 5 & 5 & 6 & 6 & & & & \\
\hline ILR & 347 & 340 & 312 & 290 & 280 & 270 & 7.4 & 0.06 & 0.01 & 0.71 \\
\hline Breakdown & 295 & 290 & 263 & 253 & 244 & 235 & 6.5 & 0.09 & 0.03 & 0.73 \\
\hline Pool size & 86 & 72 & 78 & 79 & 79 & 79 & $5 \cdot 7$ & 0.88 & 0.99 & 0.91 \\
\hline
\end{tabular}

${ }^{a, b}$ Mean values with unlike superscript letters were significantly different $(P<0.05)$.

*AA released from protein breakdown was calculated as the difference between the ILR and intake, using the steady-state model of Waterlow ${ }^{(12)}$, i.e. ILR $=$ protein breakdown + dietary intake $=$ protein synthesis + AA oxidation. Intake was estimated by multiplying the feed intake by the dietary apparent ileal digestible content of each AA and dividing by $24 \mathrm{~h}$ and the molar mass.

†There was a significant interaction. 
Table 4. Correlation coefficients for the relationships between the irreversible loss rate (ILR) index and the nutritional acute-phase index (NAPI), for the ILR index and the health status acute-phase index (HAPI), and for the ILR and nitrogen retention*

\begin{tabular}{|c|c|c|c|c|}
\hline & \multicolumn{2}{|c|}{$\begin{array}{l}\text { Pre- and day } 3 \\
\text { post-challenge }\end{array}$} & \multicolumn{2}{|c|}{$\begin{array}{l}\text { Pre- and day } 8 \\
\text { post-challenge }\end{array}$} \\
\hline & Correlation† & $P$ & Correlation† & $P$ \\
\hline ILR index for Trp $v$. NAPI & -0.45 & 0.06 & & NS \\
\hline ILR index for Val $v$. NAPI & & NS & -0.38 & 0.09 \\
\hline ILR index for Tyr $v$. NAPI & & NS & -0.48 & 0.03 \\
\hline ILR index for Trp $v$. HAPI & -0.41 & 0.09 & & NS \\
\hline ILR index for Val $v$. HAPI & & NS & -0.38 & 0.09 \\
\hline ILR index for Tyr $v$. HAPI & & NS & -0.51 & 0.02 \\
\hline ILR for Lys $v . \mathrm{N}$ retention & 0.49 & 0.03 & 0.57 & 0.01 \\
\hline ILR for Met $v . \mathrm{N}$ retention & 0.47 & 0.04 & 0.55 & 0.02 \\
\hline ILR for lle $v$. N retention & 0.50 & 0.02 & 0.53 & 0.01 \\
\hline ILR for Leu $v$. N retention & 0.36 & 0.10 & 0.51 & 0.02 \\
\hline ILR for Val $v . \mathrm{N}$ retention & 0.64 & $<0.01$ & 0.65 & $<0.01$ \\
\hline ILR for Phe $v$. $\mathrm{N}$ retention & 0.50 & 0.02 & 0.50 & 0.02 \\
\hline ILR for Tyr $v . \mathrm{N}$ retention & 0.65 & $<0.01$ & 0.68 & $<0.01$ \\
\hline Sum of ILR $v . \mathrm{N}$ retention & 0.58 & $<0.01$ & 0.69 & $<0.001$ \\
\hline
\end{tabular}

${ }^{*}$ Correlations were calculated for data obtained at day 3 post-challenge and pre-challenge, and for data obtained at day 8 post-challenge and pre-challenge in growing pigs.

$\dagger$ Pearson's correlation coefficients are presented with their $P$ value. Each correlation analysis included data of eleven pigs.

dietary protein supply. This is in line with the concept that immune functions are prioritised over other body functions during immune system activation ${ }^{(1,3)}$. The tendency for lower serum albumin concentrations during the pre- and post-challenge periods in Res-pigs than in Ad-pigs, however, indicates that a restriction in dietary protein supply can reduce albumin concentrations independent of immune system activation in growing pigs. Furthermore, this suggest that, in contrast to prioritising for immune functions, in this case APP synthesis, there is a competition for AA between immune functions and other body functions such as body protein deposition in growing pigs.

The ILR of an AA reflects the amount of free AA that disappears per unit of time from the blood plasma pool. The ILR includes the use of AA for protein synthesis and oxidation, and does not distinguish between the two fluxes. The ILR of AA in plasma in combination with the pool size or concentration of $\mathrm{AA}$ is, however, more useful for quantifying changes in AA metabolism than merely plasma AA concentrations or pool sizes. Changes in AA metabolism, e.g. an increased protein synthesis rate, can occur without concomitant changes in plasma AA concentrations or pool size, as AA concentrations can be maintained when fluxes from protein intake, breakdown and synthesis of body protein, and oxidation of AA are changing ${ }^{(14)}$. Yet, changes in plasma AA concentrations have been used previously as a measure to assess the effects of immune system activation on AA metabolism ${ }^{(15,40,47,48)}$. In the present study, the lower ILR for Val at day 8 post-challenge than at day 3 post-challenge was not associated with a change in pool size. Therefore, the use of pool size or AA plasma concentrations as a single measure to quantify the effects of immune system activation on AA metabolism can be misleading. Furthermore, $\mathrm{N}$ retention reflects the total whole-body protein deposition, and does not distinguish between $\mathrm{N}$ retained in muscle protein or APP, neither does the ILR.
The restricted dietary protein supply reduced apparent faecal $\mathrm{N}$ digestibility compared with the adequate dietary protein supply. This is probably attributed to a proportionally greater excretion of basal endogenous $\mathrm{N}$ in Res-pigs, as the relative contribution of endogenous $\mathrm{N}$ to total faecal $\mathrm{N}$ excretion decreases with increasing dietary protein supply ${ }^{(49)}$ or when AA are administered intravenously ${ }^{(50)}$. N retention was $20 \%$ lower in Res-pigs than in Ad-pigs, and corresponded with the observed reduction in the ILR for the presented AA, except for Trp. The ILR for Lys was 19\% lower in Res-pigs, followed by Met $(-18 \%)$, Leu $(-16 \%)$, Phe $(-15 \%)$, Val $(-14 \%)$ and Ile $(-13 \%)$. In addition, positive correlations were observed between $\mathrm{N}$ retention and the ILR for Lys, Met, Ile, Leu, Val, Phe and Tyr, but not for Trp. These positive correlations were mostly attributed to the differences in dietary protein supply, as the ILR indices for all AA, reflecting the changes in the ILR within the animals due to the challenge, did not correlate with $\mathrm{N}$ retention. As expected, restricted dietary protein supply resulted in lower urinary $\mathrm{N}$ excretion (absolute in $\mathrm{g} / \mathrm{kg} \mathrm{BW}^{0.75}$ per $\mathrm{d}$ as well as relative to the percentage of $\mathrm{N}$ intake), indicating that oxidation of AA was reduced in Res-pigs compared with Ad-pigs.

In the present study, immune system activation induced by CFA altered $\mathrm{N}$ retention and AA metabolism, independent of dietary protein supply. It was hypothesised that the effect of the CFA challenge on protein metabolism would be more pronounced under conditions of a marginal dietary protein supply. This would increase the competition for indispensable AA used for immune system functioning and for body protein deposition in muscle as a main determinant of the animal's growth. The effects of the CFA challenge on variables related to protein metabolism, however, were less pronounced in Respigs than in Ad-pigs. In Res-pigs there was no drop in $\mathrm{N}$ retention post-challenge compared with pre-challenge, suggesting that there is a high priority for the allocation of AA for body 
protein deposition in Res-pigs. $\mathrm{N}$ utilisation for retention, i.e. $\mathrm{N}$ retention:digestible $\mathrm{N}$ intake ratio, was greater in Respigs than in Ad-pigs as expected due to the difference in dietary protein supply. As shown by Fuller et al. ${ }^{(51)}$, the increase in $\mathrm{N}$ retention associated with an increase in dietary protein supply is proportionally smaller than the increase in $\mathrm{N}$ digestibility ${ }^{(51)}$. In Ad-pigs, $\mathrm{N}$ retention numerically decreased by $6 \%$ post-challenge, and the post-challenge drop in the ILR for Val and Tyr is, therefore, most probably attributed to a reduction in protein synthesis. In contrast, $\mathrm{N}$ retention in Res-pigs was unaffected by the CFA challenge. Therefore, the post-challenge drop in the ILR for Val and Tyr in Res-pigs can probably be attributed to a reduction in oxidation rather than to a reduction in body protein synthesis, as also indicated by the concomitant numerical decrease in Val pool size. This indicates that immune system activation reduced Val and Tyr oxidation in Res-pigs, but not in Ad-pigs. In humans, Leu oxidation decreased substantially more than Leu utilisation for protein synthesis, with 77 and $30 \%$, respectively, when a low-protein diet compared with a high-protein diet was provided ${ }^{(52)}$. A decrease in AA oxidation is possibly a compensatory mechanism in Res-pigs to spare AA from catabolism, when AA for protein synthesis are scarce. The CFA challenge increased urinary $\mathrm{N}$ excretion, and tended to reduce $\mathrm{N}$ retention and $\mathrm{N}$ utilisation for retention. In line with this finding, greater urinary $\mathrm{N}$ excretion and lower $\mathrm{N}$ retention have been observed in pigs with an activated immune system by continuous exposure to major vectors of antigen transmission ${ }^{(10)}$ or by repeated i.m. LPS injections ${ }^{(13)}$. The observed greater urinary $\mathrm{N}$ loss in the post-challenge period might be caused by increased AA oxidation of unbalanced AA, as suggested by Reeds et al. ${ }^{(7)}$. An increase in the synthesis of APP has been suggested to increase the demands for AA, especially Phe, Trp and Tyr, which can be released by the breakdown of muscle protein ${ }^{(7)}$. As the AA composition of muscle protein differs from that of APP, an imbalance in AA available for body protein synthesis can occur, leading to greater urinary $\mathrm{N}$ losses ${ }^{(7)}$. It was hypothesised that an increase in serum APP during immune system activation affects the ILR of AA, with a concomitant reduction in pool size, due to increased incorporation of (in particular aromatic) AA into APP, and increased pool size and oxidation of non-limiting AA resulting from the related AA imbalance. The 2- to 4-fold increase in APP concentrations following immune system activation was, however, not associated with an increase in the ILR of any of the AA. In contrast, the ILR for Val was lower at day 8 post-challenge than at day 3 post-challenge, and the CFA challenge tended to reduce the ILR for Tyr at day 8 post-challenge compared with day -5 pre-challenge. In addition, negative correlations were observed between the NAPI or HAPI and the ILR index for Tyr, and tendencies were observed for negative correlations with the ILR index for Trp and Val. These findings could, on the one hand, suggest that the changes in AA utilisation for growth due to the incorporation into APP are quantitatively less important than expected based on the findings in other studies $^{(6,7)}$. On the other hand, and more likely, a decrease in muscle protein synthesis during immune system activation $^{(53)}$ might have balanced the increase in AA utilisation after immune system activation due to increased incorporation of AA into APP. In the present study, however, no distinction could be made between AA utilisation for APP synthesis or for muscle protein synthesis related to growth.

Another explanation for the lower ILR for Tyr at day 8 postchallenge may be a reduced formation of Tyr from Phe. Phenylalanine-hydroxylase catalyses the formation of $\mathrm{Tyr}$ from Phe. Pro-inflammatory cytokines (e.g. interferon- $\gamma$ ) induce the expression of the guanosine-triphosphatecyclohydrolase-1 enzyme pathway and concomitantly release reactive oxygen species, which, in turn, inhibit phenylalanine-hydroxylase activity ${ }^{(54)}$. Thus, the formation of $\mathrm{Tyr}$ could be reduced after the CFA challenge.

The Met pool size was about $230 \%$ greater at day 8 postchallenge than at day 3 post-challenge in Ad-pigs, but not in Res-pigs $(P=0.03)$. The greater pool size at day 8 in Ad-pigs might be attributed to the greater release of Met from protein breakdown, i.e. Met released from breakdown increased by $11 \%$ compared with pre-challenge, and by $13 \%$ compared with day 3 post-challenge. An increase in plasma pool size at a similar ILR may indicate Met oxidation (transsulfuration) rather than utilisation for protein synthesis. Hence, Met may have been released in excess of its requirement, which corresponds with the relatively high Met content in muscle protein $^{(55)}$ compared with average $\mathrm{APP}^{(7)}$. It can be expected that Met is increasingly used for conversion into Cys in order to produce glutathione, which plays an important role in maintaining antioxidant defences ${ }^{(56,57)}$, and supports proliferation of $\mathrm{T}$ lymphocytes ${ }^{(58)}$. As shown by Litvak et al. ${ }^{(12)}$, immune system activation by i.m. LPS administration increased the optimal dietary Met:Met + Cys ratio for whole-body protein deposition.

In conclusion, the effect of the CFA challenge on $\mathrm{N}$ retention and $\mathrm{AA}$ metabolism was largely independent of the dietary protein supply. A deficient dietary protein supply decreased blood serum concentrations of CRP and, to a lesser extent, albumin, stressing the importance of an adequate dietary AA supply for the production of APP in growing pigs. Immune system activation via i.v. CFA administration increased urinary $\mathrm{N}$ excretion in growing pigs, and tended to reduce $\mathrm{N}$ retention and $\mathrm{N}$ utilisation of digestible $\mathrm{N}$ for retention. Immune system activation reduced the ILR for Val and Tyr, but did not lead to a significant change in the pool size of the measured AA, except for Met. The ILR of all AA measured, except for Trp, were strongly affected by dietary protein supply and were positively correlated with $\mathrm{N}$ retention. Correlations between the ILR and APP indices were absent or negative, indicating that changes in AA utilisation for APP synthesis are quantitatively unimportant in growing pigs, or, more likely, outweighed by a decrease in muscle protein synthesis during immune system activation.

\section{Acknowledgements}

The authors appreciate H. van Beers-Schreurs, G. J. Deetman, D. Wamsteeker and S. Thus for their assistance during the experiments. 
The present study was financially supported by the Product Board Animal Feed (PDV) in The Netherlands and the Product Board for Livestock and Meat (PVV) in The Netherlands. The Product Board Animal Feed and the Product Board for Livestock and Meat had no role in the design and analysis of the study or in the writing of this article.

The authors' contributions are as follows: E. K.-v. d. H. and P. S. conducted the experiment; J. J. G. C. v. d. B. and E. K.-v. d. H. analysed the data. All authors were involved in the design of the experiments and in the writing of the paper, and read and approved the final manuscript.

The authors had no conflicts of interest.

\section{References}

1. Klasing KC \& Johnstone BJ (1991) Monokines in growth and development. Poult Sci 70, 1781-1789.

2. Spurlock ME (1997) Regulation of metabolism and growth during immune challenge: an overview of cytokine function. J Anim Sci 75, 1773-1783.

3. Lochmiller RL \& Deerenberg C (2000) Trade-offs in evolutionary immunology: just what is the cost of immunity? Oikos 88, 87-98.

4. Le Floc'h N, Melchior D \& Obled C (2004) Modifications of protein and amino acid metabolism during inflammation and immune system activation. Livest Prod Sci 87, 37-45.

5. Baumann H \& Gauldie J (1994) The acute phase response. Immunol Today 15, 74-80.

6. Iseri VJ \& Klasing KC (2013) Dynamics of the systemic components of the chicken (Gallus gallus domesticus) immune system following activation by Escherichia coli; implications for the costs of immunity. Dev Comp Immunol 40, 248-257.

7. Reeds PJ, Fjeld CR \& Jahoor F (1994) Do the differences between the amino acid compositions of acute-phase and muscle proteins have a bearing on nitrogen loss in traumatic states? J Nutr 124, 906-910.

8. Breuille D, Voisin L, Contrepois M, et al. (1999) A sustained rat model for studying the long-lasting catabolic state of sepsis. Infect Immun 67, 1079-1085.

9. Zamir O, Hasselgren PO, Higashiguchi T, et al. (1992) Tumour necrosis factor (TNF) and interleukin-1 (IL-1) induce muscle proteolysis through different mechanisms. Mediat Inflamm 1, 247-250.

10. Williams NH, Stahly TS \& Zimmerman DR (1997) Effect of chronic immune system activation on body nitrogen retention, partial efficiency of lysine utilization, and lysine needs of pigs. J Anim Sci 75, 2472-2480.

11. Daiwen C, Keying Z \& Chunyan W (2008) Influences of lipopolysaccharide-induced immune challenge on performance and whole-body protein turnover in weanling pigs. Livest Sci 113, 291-295.

12. Litvak N, Rakhshandeh A, Htoo JK, et al. (2013) Immune system stimulation increases the optimal dietary methionine to methionine plus cysteine ratio in growing pigs. J Anim Sci 91, 4188-4196.

13. De Ridder K, Levesque CL, Htoo JK, et al. (2012) Immune system stimulation reduces the efficiency of tryptophan utilization for body protein deposition in growing pigs. $J$ Anim Sci 90, 3485-3491.

14. Waterlow JC (2006) Protein Turnover. Cambridge: CAB International.

15. Melchior D, Sève B \& Le Floc'h N (2004) Chronic lung inflammation affects plasma amino acid concentrations in pigs. J Anim Sci 82, 1091-1099.
16. Le Floc'h N, Melchior D \& Sève B (2008) Dietary tryptophan helps to preserve tryptophan homeostasis in pigs suffering from lung inflammation. J Anim Sci 86, 3473-3479.

17. Grimble RFJ, Persaud AA, Wride C, et al. (1992) Cysteine and glycine supplementation modulate the metabolic response to tumor necrosis factor $\alpha$ in rats fed a low protein diet. J Nutr 122, 2066-2073.

18. Jahoor F, Wykes L, Del Rosario M, et al. (1999) Chronic protein undernutrition and an acute inflammatory stimulus elicit different protein kinetic responses in plasma but not in muscle of piglets. J Nutr 129, 693-699.

19. Grimble RF (2001) Nutritional modulation of immune function. Proc Nutr Soc 60, 389-397.

20. Li P, Yin Y-L, Li D, et al. (2007) Amino acids and immune function. Br J Nutr 98, 237-252.

21. Le Floc'h N, Le Bellego L, Matte JJ, et al. (2009) The effect of sanitary status degradation and dietary tryptophan content on growth rate and tryptophan metabolism in weaning pigs. J Anim Sci 87, 1686-1694.

22. Calder PC \& Yaqoob P (2012) Nutrient regulation of the immune response. In Present Knowledge in Nutrition, 10th ed., pp. 688-708 [JW Erdman, IA Macdonald and SH Zeisel, editors]. Iowa: Wiley-Blackwell.

23. Li D, Changting X, Shiyan Q, et al. (1999) Effects of dietary threonine on performance, plasma parameters and immune function of growing pigs. Anim Feed Sci Technol 78, $179-188$.

24. Moffett JR \& Namboodiri MAA (2003) Tryptophan and the immune response. Immunol Cell Biol 81, 247-265.

25. Centraal Veevoederbureau (2008) Table of Feedstuff. Lelystad: Centraal Veevoederbureau.

26. ARC (1981) The Nutrient Requirements of Pigs. Slough, Berkshire: Agricultural Research Council, Commonwealth Agricultural Bureaux.

27. Doumas BT, Bayse DD, Carter RJ, et al. (1981) A candidate reference method for determination of total protein in serum. I. Development and validation. Clin Chem 27, $1642-1650$.

28. Van Kleef DJ, Deuring K \& van Leeuwen P (1994) A new method of faeces collection in the pig. Lab Anim 28, 78-79.

29. ISO 5983 (2005) Animal Feeding Stuff - Determination of Nitrogen Content and Calculation of Crude Protein Content - Part 1 Kjeldabl Method. Geneva: International Organization for Standardization.

30. ISO 6496 (1999) Animal Feeding Stuff - Determination of Moisture and Other Volatile Matter Content. Geneva: International Organization for Standardization.

31. Huang L, Hogewind-Schoonenboom JE, de Groof F, et al. (2011) Lysine requirement of the enterally fed term infant in the first month of life. Am J Clin Nutr 94, 1496-1503.

32. Holtrop G, Lapierre H \& Lobley GE (2004) Modelling transport of amino acids into the red blood cells of sheep. J Agric Sci 142, 577-588.

33. Reeds PJ, Cadenhead A, Fuller MF, et al. (1980) Protein turnover in growing pigs. Effects of age and food intake. $\mathrm{BrJ}$ Nutr 43, 445-455.

34. Vigushin DM, Pepys MB \& Hawkins PN (1993) Metabolic and scintigraphic studies of radioiodinated human C-reactive protein in health and disease. J Clin Invest 91, 1351-1357.

35. Dobryszycka W, Osada J \& Woźniak M (1979) Metabolic studies on hybrid haptoglobins. Int J Biochem 10, 75-79.

36. Petersen HH, Nielsen JP, Heegaard PM, et al. (2004) Application of acute phase protein measurements in veterinary clinical chemistry. Vet Res 35, 163-187.

37. Toussaint MJM, Ederen AM \& Gruys E (1995) Implication of clinical pathology in assessment of animal health and in 
animal production and meat inspection. Comp Haematol Int 5, 149-157.

38. Gruys E, Toussaint MJM, Niewold TA, et al. (2005) Acute phase reaction and acute phase proteins. J Zhejiang Univ Sci 11, 1045-1056.

39. Bibby J \& Toutenburg H (1977) Prediction and Improved Estimation in Linear Models. Chichester, UK: John Wiley \& Sons.

40. Melchior D, Mézière N, Sève B, et al. (2005) Is tryptophan catabolism increased under indoleamine 2,3 dioxygenase activity during chronic lung inflammation in pigs? Reprod Nutr Dev 45, 175-183.

41. Edwards JF \& Slauson DO (1983) Complete Freund's adjuvant-induced pneumonia in swine: a model of interstitial lung disease. J Comp Pathol 93, 353-361.

42. Heegaard P, Stockmarr A, Pineiro M, et al. (2011) Optimal combinations of acute phase proteins for detecting infectious disease in pigs. Vet Res $\mathbf{4 2}, 50$.

43. Litvak N, Htoo JK \& de Lange CFM (2013) Restricting sulfur amino acid intake in growing pigs challenged with lipopolysaccharides decreases plasma protein and albumin synthesis. Can J Anim Sci 93, 505-515.

44. Cray C (2012) Acute phase proteins in animals. Prog Mol Biol Transl Sci 105, 114-138.

45. Fanali G, di Masi A, Trezza V, et al. (2012) Human serum albumin: from bench to bedside. Mol Aspects Med 33, 209-290.

46. Houdijk JGM, Campbell FM, Fortomaris PD, et al. (2007) Effects of sub-clinical post-weaning colibacillosis and dietary protein on acute phase proteins in weaner pigs. Livest Sci 108, 182-185.

47. Le Floc'h N, Jondreville C, Matte JJ, et al. (2006) Importance of sanitary environment for growth performance and plasma nutrient homeostasis during the post-weaning period in piglets. Arch Anim Nutr 60, 23-34.

48. Maes M, Meltzer HY, Scharpè S, et al. (1993) Relationships between lower plasma L-tryptophan levels and immune-inflammatory variables in depression. Psychiatry Res 49, 151-165.
49. Fan MZ, Sauer WC, Hardin RT, et al. (1994) Determination of apparent ileal amino acid digestibility in pigs: effect of dietary amino acid level. J Anim Sci 72, 2851-2859.

50. de Lange CFM, Sauer WC \& Souffrant W (1989) The effect of protein status of the pig on the recovery and amino acid composition of endogenous protein in digesta collected from the distal ileum. J Anim Sci 67, 755-762.

51. Fuller MF, Cadenhead A, Mollison G, et al. (1987) Effects of the amount and quality of dietary protein on nitrogen metabolism and heat production in growing pigs. BrJ Nutr $\mathbf{5 8}$, 277-285.

52. Hoerr RA, Matthews DE, Bier DM, et al. (1993) Effects of protein restriction and acute refeeding on leucine and lysine kinetics in young men. Am J Physiol Endocrinol Metab 264, E567-E575.

53. Breuille D, Rose F, Arnal M, et al. (1994) Sepsis modifies the contribution of different organs to whole-body protein synthesis in rats. Clin Sci 86, 663-669.

54. Capuron L, Schroecksnadel S, Féart C, et al. (2011) Chronic low-grade inflammation in elderly persons is associated with altered tryptophan and tyrosine metabolism: role in neuropsychiatric symptoms. Biol Psychiatry 70, 175-182.

55. Conde-Aguilera JA, Barea R, Le Floc'h N, et al. (2010) A sulfur amino acid deficiency changes the amino acid composition of body protein in piglets. Animal 4, 1349-1358.

56. Grimble RF \& Grimble GK (1998) Immunonutrition: role of sulfur amino acids, related amino acids, and polyamines. Nutrition 14, 605-610.

57. Malmezat T, Breuillé D, Capitan P, et al. (2000) Glutathione turnover is increased during the acute phase of sepsis in rats. J Nutr 130, 1239-1246.

58. Grimble RF (2006) The effects of sulfur amino acid intake on immune function in humans. J Nutr 136, 1660S-1665S.

59. Centraal Veevoederbureau (2004) Table on Feed Ingredients. Data on the Chemical Composition, Digestibility and Nutritional Value of Feedstuffs. Lelystad, The Netherlands: Centraal Veevoederbureau. 